LBNL-40895

\title{
LARGE ORGANIZATIONS' INVESTMENTS IN ENERGY-EFFICIENT BUILDING RETROFITS
}

\author{
Susan L. Kulakowski \\ Energy Analysis Department \\ Environmental Energy Technologies Division \\ Ernest Orlando Lawrence Berkeley National Laboratory \\ University of California \\ Berkeley, CA 94720 \\ http://enduse.lbl.gov/projects/mktimperfect.html
}

May 1999

This work was supported by the Shell Oil Foundation and prepared for the U.S. Department of Energy under Contract No. DE-AC03-76SF00098. 


\section{DISCLAIMER}

This report was prepared as an account of work sponsored by an agency of the United States Government. Neither the United States Government nor any agency thereof, nor any of their employees, make any warranty, express or implied, or assumes any legal liability or responsibility for the accuracy, completeness, or usefulness of any information, apparatus, product, or process disclosed, or represents that its use would not infringe privately owned rights. Reference herein to any specific commercial product, process, or service by trade name, trademark, manufacturer, or otherwise does not necessarily constitute or imply its endorsement, recommendation, or favoring by the United States Government or any agency thereof. The views and opinions of authors expressed herein do not necessarily state or reflect those of the United States Government or any agency thereof. 


\section{DISCLAIMER}

Portions of this document may be illegible in electronic image products. Images are produced from the best available original document. 


\begin{abstract}
Case studies of two large organizations explore how and why such organizations choose to invest (or not) in energy-efficient building retrofits. The cases provide evidence for inconsistent application of budgeting procedures, predominance of payback period as a decision-making tool, existence of split incentives and moderate transaction costs facing certain energy-efficiency project proposals. Evidence also suggests the unrecognized importance of effective communication to management of the results of energy-efficiency programs and particular incentive problems faced by firms with on-site power generation.
\end{abstract}




\section{TABLE OF CONTENTS}

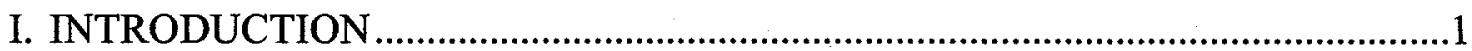

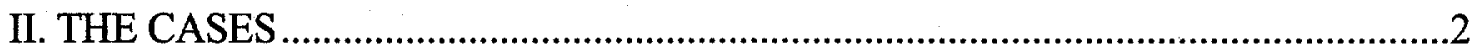

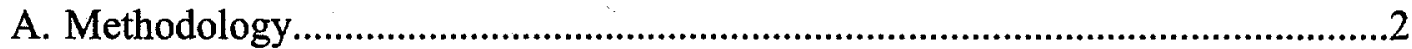

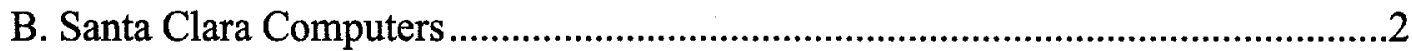

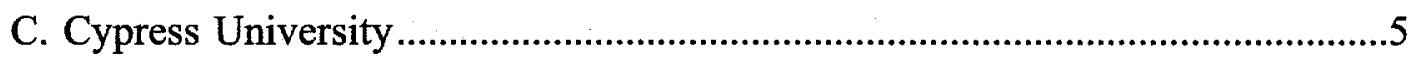

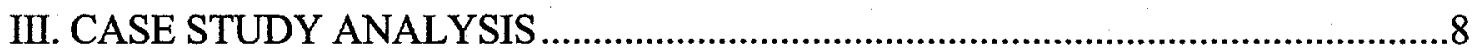

A. Evidence Regarding Theories Suggested by the Literature....................................

B. Additional Theories Suggested by the Cases..........................................................12

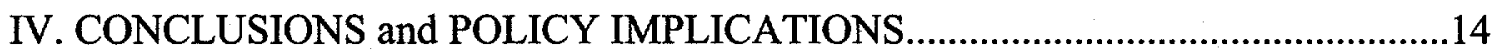

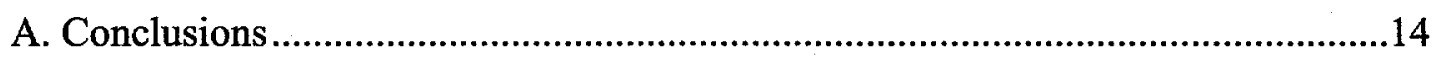

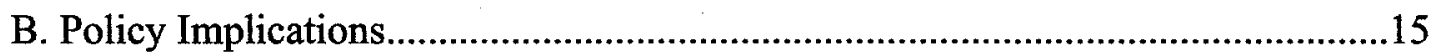

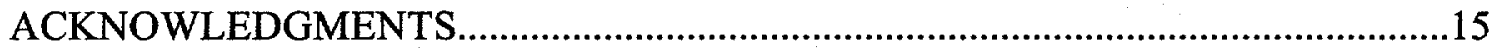

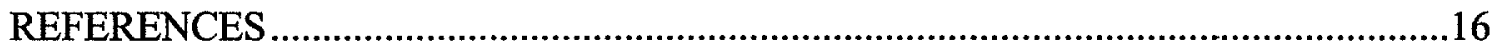

APPENDIX. LITERATURE REVIEW …………................................................

Market failures and barriers ............................................................................

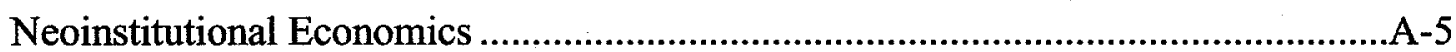

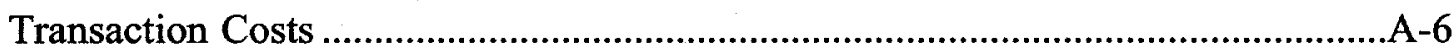

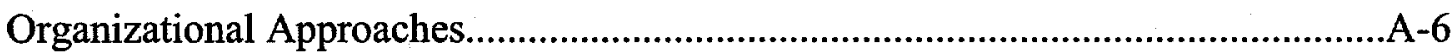

Behavioral Approaches ........................................................................................

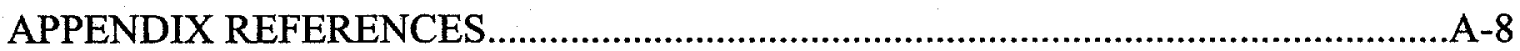




\section{INTRODUCTION}

American businesses spend $\$ 350$ billion on energy each year. ${ }^{1}$ While the majority of the nation's energy use is in the industrial and transportation sectors, the commercial sector accounted for sixteen percent of total US primary use in $1996 .{ }^{2}$ Energy use in this sector is expected to increase as the economy continues to shift from heavy industry to service and information-based business.

The financial and environmental costs associated with energy use in commercial buildings are significant. Providing energy to them in 1996 cost $\$ 96$ billion and contributed around 230 million metric tons of carbon to the atmosphere - sixteen percent of the United States' annual total. ${ }^{3}$ Commercial buildings are heavy users of electricity, with its associated conversion losses and pollution. The Department of Energy reports that the nation's offices and workplaces account for more than a quarter of peak electrical demand, a figure exceeding the capacity of all existing US nuclear power plants. ${ }^{4}$.

Some analysts (mostly engineers) believe efficiency improvements in American buildings using currently available technology could reduce energy consumption significantly. One survey of this literature gave savings figures in the range of 13 to 45 percent (Komor and Moyad, 1992). Efficiency proponents insist business is missing opportunities for improvements that would be profitable at current energy prices (even as they point out current prices do not reflect the true social cost of energy). This conclusion is based on specific examples of efficiency technologies that deliver the same services and are cost-effective, but are not adopted in the marketplace (e.g., Koomey et al. 1996). Alternately, they argue that energy costs are such a small fraction of the total cost of doing business that most firms can safely neglect or ignore them.

Other analysts (mostly economists) respond by saying any firm that does not take advantage of all profitable investment opportunities would not prosper in a competitive economy. Businesses, particularly large ones, have accountants and other professionals devoted to making the best use of the firm's financial resources. Thus, any energy-efficiency measures left undone must have costs hidden from or uncounted by external observers (such as uncertainty and inertia) which render them unprofitable (e.g., Jaffe and Stavins, 1994).

Both of these camps are prone to make sweeping statements about how and why firms choose to invest (or not) in energy-efficient building improvements. The debate over the size, causes, significance, and appropriate policy responses to the so-called "efficiency gap" or "energy paradox" (the difference between expected and observed levels of energy efficiency) is lively, but light on detailed inquiry into the particular decision making processes of actual firms. This paper is an attempt to add to the real-world foundation of economic, organizational, and behavioral theories proposed to explain the efficiency gap in existing buildings (not new construction). For a detailed review of relevant literature, see the Appendix at the end of this report. The next section presents methodology and summaries of two detailed case studies. Analysis of the case study findings is presented in Section III, followed by conclusions and policy implications.

\footnotetext{
U.S. Census Bureau, 1994.

${ }^{2}$ Energy Information Administration, 1997.

${ }^{3}$ Energy Information Administration, 1997.

${ }^{4}$ Energy Information Administration, 1992.
} 


\section{THE CASES}

\section{A. Methodology}

The purpose of this research was to explore the reasons for and the processes by which organizations allocate funds to improve the energy efficiency of their existing buildings. Yin (1989) recommends the case study as the preferred research method for situations in which the form of the research question is "how?" or "why?", the researcher does not have control over behavioral events, and the focus is on contemporary events. Therefore, the author chose to conduct explanatory case studies of two California organizations.

One of the organizations is a non-profit organization, assigned the fictitious name "Cypress University". The other is a for-profit business, assigned the pseudonym "Santa Clara Computers". Over the course of two months in early 1997 the author conducted semi-structured interviews with seven employees (five at Cypress University and two at Santa Clara Computers), including energy and facilities engineers; maintenance, financial and energy managers. The case study summaries presented below were constructed from hand-written notes, audio-tapes, documents provided by the organizations, and follow-up telephone conversations. Summaries of these interviews are presented below. Full case study reports are available from the author.

\section{B. Santa Clara Computers}

Santa Clara Computers employs 5,500 people at its headquarters site in California and 13,000 world-wide. In the last five years they have reported an average of nine billion dollars per year in net sales and 107 million dollars per year in net income. The headquarters facilities for Santa Clara Computers are located in a mild climate zone and are comprised of 25 buildings of 2.6 million square feet, containing offices, a few laboratories, and a warehouse. Santa Clara owns about onethird of the buildings, including the largest (a 900,000 square foot office building) and leases the remainder. Manufacturing facilities are located elsewhere and not considered in this case study.

Santa Clara Computers headquarters spends about six million dollars per year for energy purchased from the local utility company. Eighty-three percent (around five million dollars) goes to purchase electricity and 17 percent (around one million dollars) for natural gas. These expenditures represent approximately six percent of annual operating expenses, falling somewhere below lease payments and property taxes. Employees interviewed for this study do not consider energy an important cost of doing business at Santa Clara headquarters although it represents a significant portion (about nine percent) of the Facilities Department budget.

Santa Clara Computers uses approximately 50 million $\mathrm{kWh}$ of electricity and two million therms of natural gas annually. This consumption converts to site energy use of about 140,000 Btu per square foot, which is much higher than the national average for commercial buildings with electricity as the major fuel source (Energy Information Administration, 1993). Santa Clara Computers' higher energy intensity may be due to the imprecision of the figures provided for annual expenses and square footage, but might also reflect differences between the set of buildings used by the company and the set of buildings in the nation as a whole.

According to the Facilities Engineer who is in charge of energy management, the main drivers of energy-efficiency investment are maintenance cost savings and improvements in lighting quality that can be obtained through building retrofits. The amount of money available for energy-efficiency projects in a given year is linked to the overall financial performance of the firm. The next fiscal year's sales projections are used to predict growth and associated space needs at the Vice President of Planning level. The Facilities Business Manager uses this information in conjunction with 
budget proposals from mid-level managers to develop an annual business plan. This plan, containing requests for both capital and operating budgets, then goes back up the chain of command for consolidation and approval. Building energy-efficiency projects are just one small item in the facilities business plan. They generally fall into two categories: those that are done as a part of a larger package of improvements before a newly leased building is occupied, and "standalone" projects in occupied buildings.

The first type of project is managed by people from the firm's Design, Development, and Construction Group. The work to be done is specified by a project mechanical engineer or consultant. In either case, the stated priority is to meet the needs of the employees who will be working at the new or newly acquired buildings at the lowest initial cost. The Facilities Business Manager does "net present value" and other cash flow analyses for renovation projects, but there is no set investment decision rule for the energy component. Rather, the extent of efficiency improvements depends upon the condition of existing equipment and money available from the landlord as negotiated in the lease agreement. The lease agreement is not arranged by the construction group, but by the real estate group. The Facilities Business Manager stated that, in general, the company will include energy improvements that will pay for themselves before the lease expires.

The second type of project is seen as a way to address energy-efficiency opportunities missed during pre-lease renovation and install new technology in older buildings. Almost all of the ideas for these projects originate with the Facilities Engineer in the course of his daily work in the buildings. When the Facilities Engineer has an idea for a project, he monitors power usage of that building or electrical panel, does a rough fixture count, looks at utility bills, and uses other estimates to calculate the costs and savings. The Engineer then prepares a project proposal for submission to his boss (the Maintenance Manager), typically consisting of a cover letter and spreadsheets of cost and savings estimates. The Maintenance Manager then discusses it with the Facilities Business Manager to see if money is available for the project.

Table 1 is a typical example of the Facilities Engineer's financial analyses, closely following an example provided by this engineer. It has three columns of data listing costs and savings associated with the existing lighting system, the first year (installation and operation) of the proposed system, and additional years (operation only) of the proposed system. At the bottom are rows showing the "return on investment" as a percentage and the "investment recapture period" in years. Note there is a row to record annual cooling savings associated with the project, but only zeroes are entered because "it's just too hard to estimate." 
TABLE 1

Santa Clara Computers Typical Energy Efficiency Project Analysis

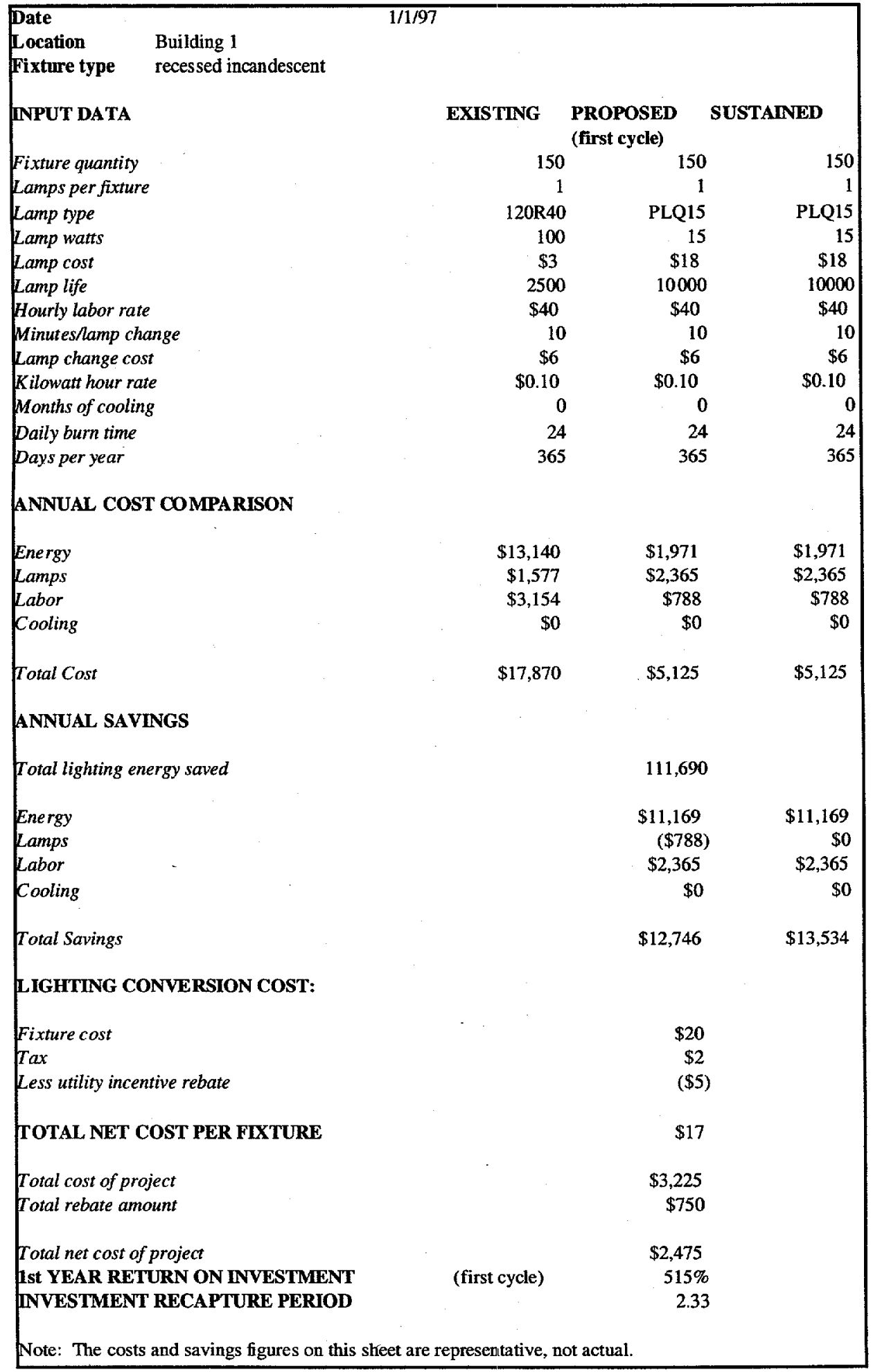


"Stand-alone" projects are evaluated individually according to a simple payback criteria. The two people interviewed for this case had different ideas about how this criteria is applied. The Facilities Engineer believes no project with a payback period longer than three years will be approved, so he doesn't submit any. He estimates one out of five of his project ideas are pre-rejected for this reason. The Business Manager, on the other hand, says he would consider projects with a longer payback period if the lease arrangement or the sheer dollar amount of savings made it sensible. They both agree the three-year payback rule is largely based on the fact that building leases are typically between three and five years in length. They also believe the firm's opportunity cost of capital is such that they can't afford to tie up money for long periods of time in energy projects. However, other sorts of investments in building improvements are not subject to a hurdle rate but are depreciated over the life of the building or lease. If, for example, a building has three years remaining on its lease, they may buy new carpeting and write off the expense for the next three years. No formal payback or other economic analysis is required.

If the Facilities Engineer gets the go-ahead from management he then prepares capital project paperwork containing a more detailed breakdown of costs, including such items as weekend/evening security and permits, but not the time he spends managing the project. There are no additional administrative costs because he does not have clerical support staff. The Engineer has also occasionally included the cost of monitoring instruments (e.g.: light loggers) in the cost of a project. If a project will cost less than $\$ 5,000$ or the equipment will have a short life, no capital project paperwork is required. This sometimes enables the Engineer to do small projects quickly and easily.

Santa Clara Computers has taken advantage of utility demand-side management (DSM) programs. The Facilities Engineer has a good, long-standing relationship with their utility account representative and estimates in the last five years Santa Clara Computers has received about $\$ 100,000$ in rebates, some of which enabled lighting projects to sneak over the hurdle rate. The company has declined other forms of utility assistance such as financing and energy audits and employees stated clearly that they often do projects without associated rebates.

Tracking the performance of energy-efficiency retrofit projects is not a priority at Santa Clara Computers. While the Business Manager actually pays the utility bills each month, it is the Facilities Engineer's responsibility to track building energy consumption. He has tried to measure the impact of his projects with simple graphs of monthly utility use in the past, but found the feedback he obtained wasn't worth the effort. However, he recently purchased utility management software which he hopes will make tracking much easier and allow him to normalize for changing weather from year to year. Management has never requested an in-depth evaluation of any of the projects or the energy management effort as a whole.

\section{Cypress University}

Cypress University is a non-profit academic institution located in a mild California climate zone. It has an annual budget of about $\$ 1.4$ billion with total assets in 1996 of approximately $\$ 7$ billion; total liabilities were $\$ 1$ billion. The university employs approximately 8,000 people, owns some 600 buildings ( 8 million square feet) and leases an additional 23 buildings (117,000 square feet). The buildings contain laboratories, classrooms, student housing, athletic facilities, offices, a hospital, libraries, and many other functions. Plant facilities net of depreciation are worth about $\$ 1$ billion.

Cypress University spends about $\$ 33$ million each year for electricity, steam, and chilled water. Utility expenses are only about two percent of the university's total annual budget, but are one of the largest single line items (after salaries, benefits, and information management systems). Some employees felt that this made energy a significant issue for the University's financial officers, while 
others felt that the attitude toward energy expenses could be expressed as: "it is what it is and there's little we can do about it."

The institution obtains all of its steam and almost all of its electricity from an on-site cogeneration plant owned and operated by a profit-making firm. Chilled water also is generated on site at a facility owned by Cypress but operated by the independent power producer (IPP). The university currently uses around 153 million $\mathrm{kWh}$ of electricity, 724 million pounds of steam, and 36 million ton-hours of chilled water annually. This converts to site energy use of approximately 105,000 Btu per square foot, which is well below the national average for commercial buildings with district heating and cooling (Energy Information Administration, 1993). Cypress University cannot participate in local utility demand-side management programs because they buy from the IPP.

The Utilities Department is the university's energy "middle-man". It purchases energy utilities from the IPP and then bills other departments for them at a higher rate, called the "re-charge rate". This re-charge rate reflects the Utilities Department's labor costs, capital costs, debt service, and other expenses. A few of the departments are distinct financial units that receive monthly utility bills, much like a typical utility customer. For the biggest department, however, the bills go directly to the Chief Academic Officer (CAO). Thus, this large department (comprised of most of the academic units) never sees a bill for its energy consumption and only the CAO's office pays attention to how much it costs to provide energy services to them. The Utilities Department is delegated responsibility for consumption forecasting, budget recommendations, and tracking usage on a building-by-building basis.

Building energy-efficiency retrofits happen at Cypress University largely because the utilities staff believes they are the proper or right thing to do. Opportunities to do retrofits arise from regulations, new faculty and research programs, and a desire for aesthetic improvements. Other drivers include maintenance cost reduction and the need to keep Cypress University's consumption within the range stipulated by their contract with the IPP.

The Energy Retrofit Program (ERP) is the brainchild of a former Utilities Manager who was frustrated with the slowness and inflexibility of using the university's capital budgeting process to fund building energy-efficiency retrofits. He obtained approval from the Facilities Director to create an account that would be allocated money annually and then drawn from throughout the year to pay for energy retrofits.

The first year of its existence (fiscal year 1993) the ERP account was allocated \$1 million. This amount was selected because it would fund a manageable number of projects. Most significantly, it was an expense that could be covered without an "unacceptable" impact on the re-charge rates. What is considered "acceptable" has changed from year to year depending upon who holds the positions of Facilities Director and CAO. In 1997 for example, the ERP account was budgeted only $\$ 500,000$ because the Facilities Director wanted to hold the re-charge rates at last year's level. Once the size of the pot of money available has been decided at higher levels, the ERP manager decides how to distribute it to various projects. Responsibility for ERP management currently rests with the Energy Engineer.

Project managers, usually maintenance staff, must submit project proposals to the ERP manager to obtain funding. There are two opportunities during the year to do this. The proposals are supposed to contain estimates of the project cost and energy savings. The Energy Engineer will assist project managers with these estimates when asked.

Table 2 is an example of energy savings calculations provided in the ERP guidelines. It contains a room-by-room description of the existing and proposed lighting systems and estimated annual energy savings. For a particular building (\#156), energy savings are calculated for both demand $(\mathrm{kW})$ and consumption $(\mathrm{kWh})$. Note that there are no financial calculations. 
Table 2. Cypress University Sample Energy-Savings Calculations, Building \#156

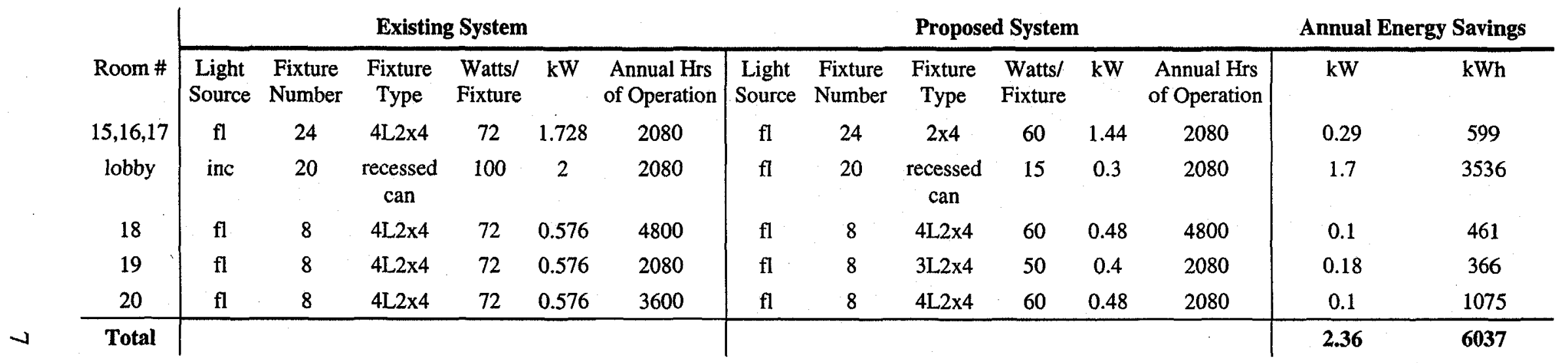

Note: The savings figures on this sheet are representative, not actual.

Abbreviations: $\mathrm{fl}=$ fluorescent, inc $=$ incandescent, $4 \mathrm{~L} 2 \times 4$ = four-lamp, two-foot by four-foot fixture 
After the Engineer receives all of the proposals, he reviews the estimates and then ranks the projects according to simple payback period. (The author was unable to obtain a copy of a spreadsheet showing how the payback calculation and ranking is done.) The ERP will only fund projects with a payback period of five years or less. This hurdle was selected because it roughly matches lamp life expectancy and it approximates a 20 percent rate of return on investment. This rate of return is considered "comfortable" because it is about double what could be earned in a typical financial market. Having a hurdle also limits the number of funding requests submitted for consideration.

In general, projects with the quickest payback period are funded first, but additional factors may be taken into account. For example, a project is more likely to obtain funding if it will also allow substantial reduction in maintenance costs or can be performed concurrently with other building projects. Projects have also been partially funded by the ERP. For example, the ERP has been used to cover the incremental cost of more efficient equipment. The Energy Engineer also tries to maintain rough funding parity between the financially independent departments and the academic departments.

According to the ERP guidelines, projects are not approved if they include "unproved technologies or will adversely affect building occupants". ERP money is also not supposed to be used for new construction or for "things that were going to be done anyway". New building construction and major renovations are handled by the Facilities Project Management group with little (but growing) input from the maintenance, operations, and utilities groups.

Energy staff has devoted modest time and effort to measuring the results of their efforts to improve building energy efficiency. The Energy Engineer feels while it is worthwhile to measure project performance, limited staff resources make it necessary to devote most time to new projects. The Utilities Department does track overall campus energy consumption for planning and forecasting purposes. They have found that while steam and chilled water use has been steadily growing at a rate of three to five percent per year, the rate of growth in electricity consumption slowed in 1994 and usage has actually declined in 1995 and early 1996. This trend is a marked change from the prior four years of rapid growth in electricity use and utilities staff partly attribute it to the success of the Energy Retrofit Program.

\section{CASE STUDY ANALYSIS}

The purpose of the case study research was to discover if the detailed evidence gathered in these two organizations tended to support or refute theories presented in the literature ${ }^{5}$ or would generate some new theories to better explain how and why organizations perform energy-efficiency improvements in buildings. This analytical method is supported by Yin (1984), who writes, "...case studies, like experiments, are generalizable to theoretical propositions and not to populations or universes" (p. 21).

\section{A. Evidence Regarding Theories Suggested by the Literature}

(1) Energy efficiency projects have a different capital budgeting request procedure and face a higher "hurdle rate" than capital improvement projects of comparable risk.

At both organizations, energy-efficiency retrofit projects are not only on an uneven playing field with other capital improvement projects, they are not even on the same field.

\footnotetext{
${ }^{5}$ See Appendix.
} 
At Cypress University, building energy retrofits are treated as an expense. This means that the Energy Retrofit Program (ERP) must compete with items such as salaries and office supplies for annual funding. As mentioned in the Cypress case above, energy projects used to be treated as capital projects, but they didn't fit very well in a year-long process designed to fund few, large projects such as steam line extensions. Utilities staff found it difficult to specify several dozen lighting projects a year in advance and go to the Board of Trustees for funding approval.

On the other hand, capital projects are not subjected to strict financial review ${ }^{6}$ while the ERP must prove its worth each year. This seems to be largely a matter of convincing managers that improving energy efficiency is "the right thing to do" but also has led the ERP manager to try to keep the payback period for the program as a whole under five years. The focus on payback period for the program and for individual projects creates an illusion that energy retrofits are considered financial investments, when they clearly are not (as noted above, they are funded out of an expense budget). The financial managers who decide how much of the University's money to invest in stocks versus treasury bills are located in an entirely different branch of the organization and energy efficiency never reaches them as an investment opportunity, only as an expense grouped under "Facilities Overhead".

At Santa Clara Computers, "stand-alone" energy retrofit projects are treated as capital projects but must go through a stricter funding procedure than other building improvements. Items such as new carpeting or office furniture are subject to an informal cost-benefit analysis and their purchase cost depreciated over the life of the lease or building. In contrast, building energy-efficiency projects must show that they will pay for themselves within three years. Again, this emphasis on a financial measure (payback period) does not mean that energy efficiency competes with other financial investments in Santa Clara Computers' portfolio. While the number and size of projects approved in a year is more closely tied to the financial performance of the firm as a whole than at Cypress University, energy efficiency remains within the realm of facilities and not the institution's financial planners.

(2) While discounted cash flow evaluations are performed for most building energy-efficiency projects, managers rely on simple measures such as payback period to make their decisions.

The first half of this theory, "discounted cash flow evaluations are performed for most building energy-efficiency projects" is not supported by evidence at either organization. While both organizations calculate something they call "internal rate of return" (IRR) neither of them perform the operation correctly. IRR is supposed to be the discount rate at which the net present value (NPV) of a project would be zero, but Cypress University's Energy Retrofit Program evaluation report equates "internal rate of return" to the average annual savings divided by average annual costs for the program. The sample project cost analysis for Santa Clara Computers (see Table 1 above) shows "first year rate of return on investment" as the first year's savings divided by the project cost and calculates the "investment recapture period" as the same figure divided into twelve to obtain payback period in months.

In contrast, the second half of this theory, "managers rely on simple measures such as payback period to make their decisions" is strongly supported by evidence at both of the organizations. At Santa Clara Computers and Cypress University, the only financial measure that matters for regular building energy retrofits is payback period. However, their reasons for relying upon this measure are quite different.

\footnotetext{
${ }^{6}$ Annual lists' of utility system capital project proposals are generated by the utility system managers. The financial analysts and senior management tend to defer to the system managers' professional opinions about what projects need to be done and how much they will cost or save the university in the long run.
} 
At Santa Clara Computers, the payback period metric is used to insure that any money they put into a building will be recovered before the lease is up for renewal. Even though leases are often renewed and the company owns many buildings, facilities staff believe their three-year payback rule protects them from doing anything someone else might benefit from. The uncertain, rapidly changing business climate they face seems to encourage the firm to "get in, save some money, get out."

At Cypress University, energy managers believe the five-year payback hurdle is consistent with the expected life of most of their projects (lighting) and use the payback period as a guide for determining which projects to do first. More important, they strive to keep the payback period of the entire Energy Retrofit Program under five years so they can show they are making good use of the funds they have been allocated, not to demonstrate that energy projects are performing better than other investments the university might make.

Most economists agree that the payback method, though popular, has several drawbacks. First, it disregards cash flows that occur after the project has paid for itself. This can cause underinvestment in projects whose benefits accrue later or grow over time (a characteristic of efficiency projects if energy prices are expected to rise in the future). Second, the standard payback period calculation ignores the time value of money, i.e.: this calculation treats a dollar saved today as if it were worth the same as a dollar saved in five years. While a discounted payback method exists, neither of the organizations in the study use it. This practice of using simple payback as a decision rule for all types of investment decisions may or may not be damaging to the organization as a whole. Statman and Sepe (1984) conducted an empirical test of 95 firms and found "...there is no support here for the claim that the use of payback [for investment decisions in general, not those related to energy-efficiency improvements in particular] compromises the goal of stockholder wealth maximization" (p. 64).

(3) Decisions about building energy efficiency are systematically affected because the groups who receive the benefits of energy cost reduction are financially separated from those who bear the cost of the investment.

This theory is supported by evidence at Cypress University only. Most of the academic departments are not directly responsible for their energy expenses. Rather, a certain portion of their combined budgets is set aside each year in an account for paying utility bills. The Utilities Department manages this account on behalf of the Chief Academic Officer, but is not allowed to keep any money left over at the end of the year. Therefore, the department has less incentive than it otherwise might to incur costs to reduce energy consumption. On the other end, individual academic departments have little incentive to reduce energy consumption because they won't necessarily receive left-over money in the following year's budget, either. Academic departments with low energy use end up subsidizing large energy users. ${ }^{7}$

At Santa Clara Computers, responsibility for energy bills and energy retrofits lies in the same department. The Facilities Business Manager pays the monthly bills and approves energy retrofit project expenses so we see no split incentives here.

\footnotetext{
${ }^{7}$ It is as if the annual utility bill for an entire apartment building were split evenly between the units regardless of size, number of occupants, etc.
} 
(4) More management attention is spent on projects that cost a lot (either relatively or absolutely). Therefore, smaller projects are ignored. This can have two results: a) Small projects remain unfunded because they have relatively high transaction and management attention costs. OR $b$ ) Small projects obtain funding easily because procedures are set up so as to require little managerial attention.

This theory seems to play itself out in several different ways at each organization. At Santa Clara Computers, small projects (less than $\$ 5,000$ or with a life less than five years) can obtain funding more easily because they side-step paperwork and approval processes. If the Facilities Engineer wants to spend his budget on compact fluorescent lamps, for example, he can do so without submitting a justification or capital plan.

At Cypress University, small projects appear to be at a disadvantage unless they are pilot projects to test new technology. The hassle of submitting and managing projects are such that larger projects make more sense. For example, this year the university grouped lighting upgrades in fifteen small buildings together as one energy retrofit project to achieve economies of scale on paperwork, bidding, etc. There is a limit to the size advantage, however. The Energy Engineer is reluctant to spend the entire ERP budget on one or two large projects when he could fund a number of smaller ones in a year. Also, since all projects must be completed by the end of each fiscal year there is a limit to their size given available staff. How many projects have been foregone for these reasons is unknown, but is likely to be a small number since the Engineer spoke of these constraints only in hypothetical terms.

(5) Organizations are more likely to invest in familiar technology or delay investment because facilities managers are risk averse and often rewarded for "playing it safe".

This theory has some supporting evidence at the two organizations. At Cypress University, the facilities staff tries to be "invisible": if nobody pays attention, they figure they're doing their jobs right. This attitude leads them to adopt new technology slowly and cautiously. At the same time, certain building occupants demand that the Facilities group "do something" about energy waste at the university. Since Utilities Department employees sympathize with this demand, it has led them to test a number of new technologies, and even support an entire building lighting retrofit as a class project. Cypress is also confident enough in new lighting technology to join the EPA's Green Lights program.

At Santa Clara Computers, the decision to delay joining Green Lights may be more a reflection of the shaky financial position of the company than lack of confidence in new lighting technology. Santa Clara Facilities employees report that they have been "willing and eager" to adopt new energy-efficiency technologies. While this willingness to test out the latest technical advances may be unusual for a large company, in Santa Clara's case it is consistent with a corporate culture that values innovation, "technology" in general, and has consistently supported improvements to the working environment.

(6) Managerial compensation is often tied to recent performance. Facilities compensation and prestige is low in general. Therefore, facilities managers have particular incentives to select quick payback projects with low risk.

This theory seems to be supported by evidence at some levels of both organizations, but not at others. At Santa Clara Computers, the Facilities Business Manager encourages or discourages project submission according to the firm's recent financial performance. The Facilities Engineer is sensitive to these trends, but doesn't believe his compensation is tied to financial performance measures. He might get a larger raise if he can show that he is saving the company a larger amount of money, but other responsibilities of his job weigh more heavily in his performance evaluations. 
The Energy Engineer at Cypress University faces a similar situation in that his compensation is not directly tied to the financial performance of the Energy Retrofit Program. He does have an interest in seeing the program survive, so tries to distribute the funds in an equitable (between departments), logical fashion. For lighting retrofits, the Engineer believes this means funding the projects with the shortest payback periods first, but suggested he might use a different methodology when they start doing more heating, ventilation, and air-conditioning (HVAC) retrofits. In any case, the Engineer wants to have a defensible system for selecting and prioritizing projects so he can continue to do work he finds (emotionally) rewarding and worthswhile.

The Facilities Director (three layers of management above the Engineer) seems more sensitive to the financial impact of the ERP and how his division's performance will be evaluated. One could interpret the 50 percent budget cut to ERP in 1997 as an easy way to reduce overhead expenses and help keep the re-charge rates at last year's levels. If senior managers value reduced overhead and constant rates over energy cost avoidance, the Facilities Director will be rewarded for his actions.

Facilities Department prestige is self-reported as low at both organizations. However, general funding for facilities has been more generous at Santa Clara Computers, perhaps because the Facilities group has a good reputation and the company is more strongly motivated to ensure peak employee performance. The Facilities Division at Cypress also has to fight the (perhaps outdated) perception that money allocated to it is wasted on poor maintenance work.

\section{(7) Utility demand-side management (DSM) programs reduce the initial expense of building energy-efficiency projects, thus enabling projects to receive approval under typical decision rules. Organizations who take advantage of utility DSM programs are therefore able to do more projects than they otherwise would.}

The best direct evidence to support this theory is found at Santa Clara Computers since they have taken good advantage of utility rebate programs. The Facilities Engineer reports that utility rebates have allowed some of his projects to clear the three-year-payback-period hurdle rate that otherwise would not. Of course, we don't know if these projects would have been approved if they had been submitted with a slightly longer payback period (since it would have been at the discretion of the Business Manager), but the fact that the rebates enabled the Engineer to meet what he perceived as a hard-and-fast standard had the result of enabling more projects to happen.

The situation at Cypress University is less clear, since only a few buildings are eligible for the regional utility's DSM programs. However, if you think of the Energy Retrofit Program as a Utilities Department DSM program and the maintenance group as a large customer, the evidence clearly supports this theory. The Academic Maintenance Manager stated that ERP funding has enabled them to do accelerated or additional work that they otherwise would not be able to afford. The fact that energy savings accrue along with the new lights or motors is somewhat incidental to the maintenance group, but is valuable to the Utilities Department.

\section{B. Additional Theories Suggested by the Cases}

\section{(1) One reason energy-efficiency programs have trouble maintaining support is that it is difficult to measure and communicate their results to management.}

Evidence gathered at both organizations suggests this theory. At Cypress University, student (i.e., cheap) labor has been enlisted to try to measure the energy savings of the Energy Retrofit Program. The students have used several different graphical methods to convey the success or failure of projects done in the name of energy efficiency. Unfortunately, some of these methods shed more light on how much they don't understand about what might be going on than what savings they can attribute to energy-efficiency projects. In several instances, for example, they found building energy 
use increased after an efficiency retrofit project was done. While there are many reasons why a building might show this pattern of energy use, ${ }^{8}$ managers reviewing such results might be led to conclude that project managers or engineers are over-estimating the money-saving potential of energy-efficiency improvements. As a result, managers might demand even shorter project payback periods to compensate for this apparently optimistic bias. ${ }^{9}$ More precise monitoring tools (such as light or power loggers) could overcome this problem, but would require additional funds and staff time.

While one might expect tight performance monitoring of cost-cutting measures at a profit-driven firm, Santa Clara Computers' measurement methods to date are even cruder than those used by Cypress. The Facilities Engineer has tried to use consumption information from utility bills to demonstrate the effect of his projects by charting whole-building $\mathrm{kWh}$ use in the same months two years in a row; one before and one after the retrofit. An example of one of his evaluations appears in Figure 1 below. Note that the date of the retrofit is not provided, rendering the chart useless without accompanying explanation. Also, the way the chart is constructed makes it difficult to compare the same month from one year to the next. A manager reviewing such poor bar charts might not get the message that energy use had decreased from one year to the next (presumably due to the installation of energy-efficient technology), or attribute the change to some other factor such as weather or building occupancy. Thus, he or she might not be persuaded to fund additional efficiency improvements.

Figure 1.

\section{Santa Clara Computers Sample Evaluation of Electricitv Use Before and After Project}

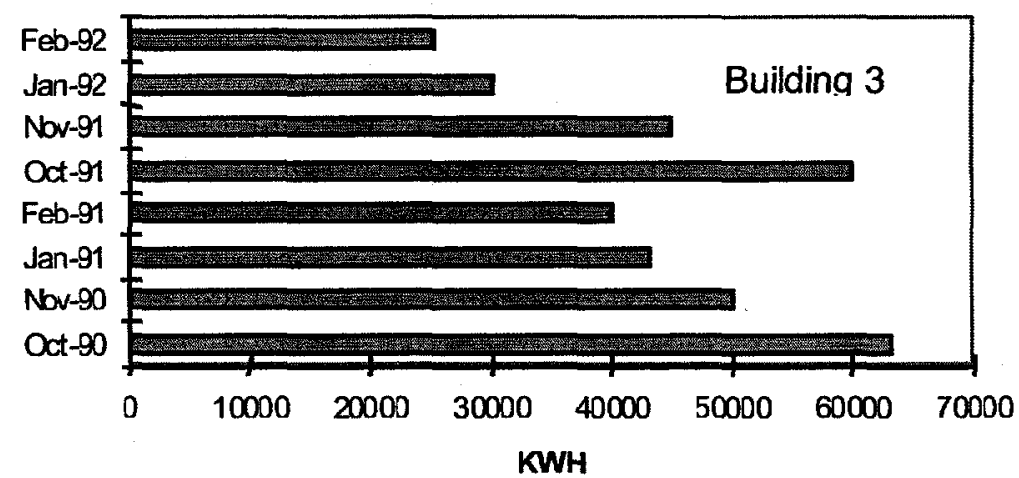

${ }^{8}$ Examples include: planned project savings small compared to total building consumption, large swings in annual consumption due to weather or occupancy changes, maintenance savings not measured, background growth in energy consumption (i.e., plug creep), equipment failure

${ }^{9}$ Statman and Tyebjee (1985) found that people who regularly evaluate capital investment project forecasts consider the forecasts overly optimistic and mentally adjust them to correct for perceived bias. 
(2) An organization that produces or maintains its own utilities may create a situation in which improved energy efficiency is discouraged.

This theory was suggested by the situation at Cypress University, which resembles that of many utility companies prior to the integrated resource planning/DSM revolution. The Utilities Department purchases energy from the privately owned cogeneration facility located on the campus. This is a more-or-less fixed cost that only changes with long-term trends in the price of the primary fuel (natural gas). The Utilities Department then re-sells the energy to other university departments at a price that incorporates its variable costs of system expansion, maintenance, administration, and the Energy Retrofit Program. The fewer units of energy (e.g., kWh, tons) the department sells, the fewer units it has over which to distribute its variable costs, so the rate charged to the other departments may have to increase. Raising rates for this reason is politically unacceptable since such "overhead" costs are assumed to be under the control of the Utilities Department in a way that the cost of purchased energy is not. Thus, there is a disincentive to improve energy efficiency beyond a certain point under the current system of accounting and accountability. While the Cypress University case is fairly unique, such situations may become more common under utility deregulation as cogeneration is projected to increase among large power users.

\section{CONCLUSIONS AND POLICY IMPLICATIONS}

\section{A. Conclusions}

Price still matters. The price of energy and of energy-efficient technologies are vitally important in determining which projects get done and which do not. While hurdle rates based on payback period may be misguided (see Case Study Analysis, Section A), they exist. This means higher initial costs for efficient technologies and artificially low (via externalities) energy prices work against energyefficient building improvements.

Organizational structure, procedures, and culture also matter. As these cases have demonstrated, the way people are organized into hierarchies and groups, operational rules designed to impose order and restraint, and shared institutional values can strongly influence the availability of funds for energy-efficiency improvements. Such observations align with those of DeCanio (1994) and Cebon (1992).

Finally, individual values and behavior also matter. The personal commitment of facilities employees to the goals of energy efficiency and its associated environmental benefits are vital to insuring program success and continued funding. If line employees were not able to convince management that improving energy efficiency is the (morally) right thing to do and take personal initiative to see projects completed, we would see even fewer energy-efficiency projects than we do now. Yet the same organizational structures that constrain certain actions may also allow managers to pursue goals they believe are good for the organization and society as a whole. A savvy leader can work the system in ways that make it easier to accomplish certain objectives as, for example, the Cypress Utilities manager did when he took energy-efficiency projects out of the ineffective capital budgeting process. This worked well when his boss (the Facilities Director) was an energyefficiency champion, but less well since the position has turned over to someone with different priorities. 


\section{B. Policy Implications}

Golove and Eto (1996) offer three rationales for government intervention in the market for energyefficient goods and services: 1) when the market is not achieving the socially optimal distribution of wealth, income, or property rights; 2) when the transaction costs associated with investments in energy efficiency are high in the market as currently structured and substantially inhibit such investments; or 3) when government can help individuals and organizations help themselves (p. 30).

As stated above, the price of energy sends a vitally important signal to decision-makers. If that price is too low due to un-internalized externalities (as many have argued elsewhere), even perfect application of economic analysis tools (an infrequent occurrence, the evidence suggests) will lead to levels of investment below what would be optimal for society. In such cases, policy interventions in the form of pollution or consumption taxes, for example, would be appropriate.

Transaction costs seem to be relatively insignificant for "stand-alone" energy retrofit projects at both organizations. This is consistent with the findings of Hein and Blok (1994). However, such costs appear to increase dramatically as soon as energy-efficiency opportunities arise in larger renovation efforts or new construction. If such situations are typical of large organizations, then policy intervention in the form of building and equipment efficiency standards, for example, could improve social welfare.

Finally, evidence provided by these two cases suggests there exist opportunities for government to help firms help themselves become more profitable. Currently, decisions about how much money to spend on energy-efficiency improvements are made in facilities departments. As a consequence, improving energy performance is not one of the investment opportunities considered by the organizations' money managers. Over in the corporate finance departments they never seem to ask themselves: "Should we invest in more Campbell's soup stock or more energy efficiency?" As long as this organizational structure persists, energy efficiency will remain marginalized - living on scraps from already-stretched facilities operations budgets. Government-sponsored executive training on how to set up "Energy Management Profit Centers" might be one way to begin to overcome this structural problem. ${ }^{\text {I }}$ In order to make the most of existing opportunities, we need to recognize that energy efficiency is not just a matter of supply and demand, but a product of complex interactions between people with different values and abilities to express them through complex organizations.

\section{ACKNOWLEDGMENTS}

This paper is a revised version of a master's project prepared for the Energy and Resources Group at the University of California, Berkeley. The author thanks Alan Sanstad, Stephen DeCanio, Richard Norgaard, Jonathan Koomey, and fellow ERG students for guidance and helpful comments. This work was supported by the Shell Oil Foundation and prepared for the U.S. Department of Energy under Contract No. DE-AC03-76SF00098.

${ }^{10}$ DeCanio (1994) proposes organizations create Energy Management Profit Centers or Energy Service Centers with their own capital allocation, the authority to make internal 'loans' to operating divisions to install energyefficient technology, and performance evaluations based on earnings. 


\section{REFERENCES}

Cebon, Peter B., "Twixt Cup and Lip: Organizational Behavior, Technical Prediction and Conservation Practice", Energy Policy, September, 1992, pp. 802-814.

DeCanio, Stephen J., “Agency and Control Problems in US Corporations: The Case of Energyefficient Investment Projects", Journal of the Economics of Business, 1:1, 1994, pp. 105-123.

Energy Information Administration, Monthly Energy Review. DOE/EIA-0035(92/06. June, 1992.

Energy Information Administration, Commercial Buildings Energy Consumption and Expenditures 1992. DOE/EIA-0318(92). 1993.

Energy Information Administration, Annual Energy Outlook 1998, With Projections Through 2020. DOE/EIA-0383(98). December, 1997.

Golove, William H. and Eto, Joseph H., "Market Barriers to Energy Efficiency: A Critical Reappraisal of the Rationale for Public Policies to Promote Energy Efficiency", Lawrence Berkeley National Laboratory, Berkeley, CA, March, 1996.

Hein, Lars G. and Blok, Kornelis, "Transaction Costs of Energy Efficiency Improvement", European Council for an Energy Efficient Economy, 1994.

Jaffe, Adam B., and Robert N. Stavins, "The Energy-Efficiency Gap: What Does It Mean?" Energy Policy, 22:10, 1994, pp. 804-810.

Komor, Paul and Moyad, Andrew, "How Large Is the Cost-Effective Energy Savings Potential in U.S. Buildings?", ACEEE Summer Study on Energy Efficiency in Buildings, 1992, pp. 6.1256.133 .

Koomey, Jonathan, Alan H. Sanstad, and Leslie J. Shown, "Energy-Efficient Lighting: Market Data, Market Imperfections, and Policy Success", Contemporary Economic Policy, 14:3, 1996, pp. 1-14.

National Audobon Society and Croxton Collaborative, Architects, Audobon House: The Building of Environmentally Responsible, Energy Efficient Offices, John Wiley \& Sons, New York, NY, 1994.

Ross, Marc, "Capital Budgeting Practices of Twelve Large Manufacturers". Financial Managemen, Winter, 1986, pp. 15-22.

Statman, Meir and Tyebjee, Tyzoon, "Optimistic Capital Budgeting Forecasts: An Experiment", Financial Management, Autumn, 1985, pp. 27-33.

U.S. Census Bureau, Office of Statistics, Statistical Abstract of the United States, 1994, 1994, p. 587. 


\section{APPENDIX. LITERATURE REVIEW}

Many scholars have puzzled over the energy paradox. Some have concluded that no gap between measured energy use and achievable efficiency potential exists, while others claim to have shown that there is systematic under-investment in energy efficiency throughout the economy. ${ }^{1}$ Of those who agree about the existence of a gap, there is disagreement about its size, severity, and policy implications. What is one to make of all this?

My reading suggests that much of the confusion may be sorted out by clarifying the distinct theoretical frameworks that provide the basis for formulating questions and defining evidence in this body of literature. Many seemingly contradictory conclusions may be understood by recognizing the different approaches to investigation of the efficiency gap. These approaches or frameworks may be categorized as follows:

- neoclassical economics,

- neoinstitutional economics,

- organizational approaches, and

- behavioral approaches.

The neoclassical economics approach is probably most familiar to readers and is the dominant one of researchers who question the existence of an efficiency gap. The approach contains an investment theory which may be characterized for our purposes as, "Firms will purchase building energy efficiency until the discounted marginal benefit generated by improvements equals the marginal cost of further improvement." Thus, almost by definition, all firms invest in just the right amount of energy-efficiency improvements. According to neoclassical theory, sub-optimal amounts of investment (either too much or too little) only occur in a few carefully defined situations called market failures. Market failures are caused by the existence of externalities, public goods, and imperfect competition (monopoly and monopsony).

Neoclassical economists admit there are failures in the market for energy efficiency. Energy prices do not fully internalize the environmental and health costs to society from power generation. Firms who are late adopters of new efficiency technology do not pay for the learning experiences of early adopters, which result in an improved product or application.

The term "market barrier" was invented by energy engineers and is used in the literature in two ways: first as a catch-all phrase to describe anything which appears to impede adoption of energyefficiency technologies (including market failures), and second as phenomena distinct from and in addition to market failures that prevent firms from optimizing energy-efficiency investment. Much of the controversy over the severity of the efficiency gap seems to have been caused by disagreement over what constitutes a market failure versus a market barrier. I have reviewed the literature below under the heading "Market Failures and Barriers" to acknowledge this dual usage and occasional conflation.

Most market barriers (in the second sense) are identified by energy researchers in response to what they consider unrealistic assumptions of the neoclassical economic approach, such as the existence

\footnotetext{
1 "Achievable efficiency potential" (as defined by energy engineers) is the difference between the level of energy use now observed and the level that would be observed if all cost-effective (i.e., cheaper than new energy supply at current prices) energy efficiency measures were implemented.
} 
of a perfect capital market, perfect certainty and complete information, firms act strictly as price takers, and zero costs associated with trade. ${ }^{2}$

An entire sub-field of economics has sprung up to try to make the neoclassical approach more realistic, yet still useful as a model of economic behavior. I will call this sub-field "neoinstitutional economics", though it is known by other names. ${ }^{3}$ Eggertsson's 1990 book entitled Economic Behavior and Institutions describes this new field. Neoinstitutional economics retains the "core" elements of neoclassical economics (stable preferences, rational choice, and equilibrium), but introduces information and transaction costs and the constraints of property rights. ${ }^{4}$ This branch of economics relaxes the assumptions of utility maximization by consumers and profit maximization by firms. It also asserts, "...measurement costs systematically influence the structure of contracts and the organization of markets and of economic institutions in general..." (Eggertson, 1990, p. 27). The neoinstitutional economics approach might be summarized for our purposes as, "If everyone could know everything for free, then firms would purchase building energy efficiency until the discounted marginal benefit generated by improvements equals the marginal cost of further improvement."

Milgrom and Roberts 1992 textbook entitled Economics, Organizations, and Management is considered one of the best representatives of this recent trend in economic thought. Rather than presenting the idealized world of profit-maximizing firms buying and selling in a friction-less world with perfect information, they describe a more realistic economic model. This world contains risks, uncertainty, moral conflict, and limited information and human capacity for understanding and optimization.

Milgrom and Roberts (1992) also discuss transactions cost economics and its limitations. Transaction cost economics is based largely on the work of Ronald Coase (1937) and Oliver Williamson (1989) and focuses explicitly on the information, negotiation, contractual, and enforcement costs assumed away by neoclassical economists. Previous work by Milgrom and Roberts (1987) enriched the discussion of transaction costs by arguing that political and influence costs are among the most crucial associated with negotiating agreements to exchange and become higher as organizations increase in size and centralized discretionary authority. I see this field of inquiry as a sub-set of neoinstitutional economics approaches, but one that has received enough attention to merit its own heading in the review below.

The organizational approach is based primarily on the work of Richard Cyert and James March (1963). They revolutionized thinking about the firm by regarding it as a hierarchical but imperfectly coordinated body composed of sub-units with perhaps different goals, views, attitudes, interests, and constraints. The firm does not maximize profits: instead it produces enough profits to survive (it satisfices). The firm's capital may be owned by people other than its managers, each of whom may have different values, goals and interests. ${ }^{5}$ Organizational approaches to investment decisions might be characterized for the purpose of this paper as, "If people were perfectly organized (with properly structured incentives, etc.), then they would purchase the amount of building energy efficiency that would provide sufficient profit to the owners of the firm."

\footnotetext{
${ }^{2}$ Velthuijsen (1995), p. 27

${ }^{3}$ This general school of thought is also known as "transaction cost economics", "modern neoclassical theory", "institutional economics", and "information economics". Each one has a slightly different set of assumptions and modifications to neoclassical theory.

${ }^{4}$ For the purpose of this review I include Herbert Simon's (1957) concepts of bounded rationality and satisficing in the neoinstitutional approach (as Velthuijsen does but Eggertson does not) because in this framework decisions remain "logical" but limited by human capacity to absorb information and foresee all possible outcomes.

${ }^{5}$ Velthuijsen, 1995.
} 
Several concepts within the organizational approach are particularly relevant to this review: organizational slack, capital rationing, and moral hazard. "Slack" occurs in an organization when more money is dedicated to a particular sub-unit than is strictly needed to perform its functions. This slack is typically hoarded by managers to provide "extras" like Friday morning donuts or offer up as budget cuts when times are tight. In the organizational view, unexploited opportunities for profitable energy-efficiency improvement would be a form of slack. Capital rationing attempts to prevent slack from accumulating by forcing projects to compete with each other for funds instead of against a profitability standard. In a firm with capital rationing we might therefore expect to see some cost-effective energy projects remain unfunded because they aren't as profitable as other projects the firm might undertake. Finally, the term "moral hazard" in this body of literature refers to "...any behavior under a contract that is inefficient, arises from the differing interests of the contracting parties, and persists only because one party to the contract cannot tell for sure whether the other is honoring the contract terms" (Milgrom and Roberts, 1992, p. 197). Moral hazard is a type of "principal-agent problem" in which parties to a contract have divergent interests. A property management company that leases a building to a firm which pays its own utility bills is a classic example of a situation in which the agent (the property manager) has no contractual incentive to act in the best interest of the principal (the lessee) by making the building more energy-efficient.

Behavioral approaches focus on individuals within firms and how they act to fulfill their own values and needs in an organizational setting approaches and may for our purposes be summed up as, "Firms purchase as much building energy efficiency as the people working in them feel they should". In this approach, actions and decisions which do not appear "rational" from an external perspective may be understood in technical, personal, social, and political terms at the same moment. ${ }^{6}$

Social scientists James March and Johan Olsen $(1976,1986)$ have developed widely used models of decision-making in which problems, solutions, and participants are joined by no more than the fact that they occur simultaneously. These processes are described by the "garbage can" metaphor because problems are linked to solutions and decision-makers to choices by just being around at the same time (getting pulled from the garbage can together). Such models are an attempt to explain observations of seemingly chaotic decision-making processes driven by limited rationality, conflict, and preference ambiguity in the midst of constant organizational change.

Phenomenon such as forecast and selection bias and individual and group psychoses are particularly relevant to the discussion of energy-efficiency decision-making. For example, Statman and Tyebjee (1985) found that the people who evaluate projects' financial forecasts recognize they are often overly optimistic and make a mental adjustment to compensate for probable bias. This behavior protects decision-makers from approving some poor projects but also causes them to reject some projects that would be profitable for the firm. Pruitt and Gitman (1987) continued Statman and Tyebjee's work with a mail survey of Fortune 500 companies. Their results support earlier conclusions and suggest some possible explanations for forecast optimism including "myopic euphoria" (people closely involved with a project can't see its faults), "groupthink" (members of a group are afraid to speak out against prevailing opinion about a project's merits), and "salesmen's optimism" (someone trying to sell a project can only see its good points).

In this review I deliberately exclude literature on innovation and individual consumer behavior or values. While "technical innovation" may characterize energy-efficiency technologies in other sectors, I believe it is not an appropriate word to describe technologies used to improve energy efficiency in existing commercial buildings. More efficient fluorescent light bulbs, occupancy sensors, HVAC control systems, variable speed motor drives, window shades and films - these are all retrofit technologies that have been around for some time. As a consequence, I view the perceived

\footnotetext{
${ }^{6}$ Jones' $^{\prime}(1989)$ "socio-rational model" as described by Northcott, 1992, p. 129.
} 
investment shortfall not as a technology problem, but a people problem. At the same time, I believe people organized into firms are significantly different from people acting as individual consumers.

People in firms may bring knowledge, money, and other resources to bear on the question of "how much should I spend on energy-efficiency improvements" unavailable to a typical homeowner. At the same time, goals and actions of people in firms may be constrained in different ways than those of a consumer who does not have to answer to bosses or shareholders. For these reasons (and to keep this review a manageable length) I have excluded research about individual energy consumers.

\section{Market Failures and Barriers}

- Koomey (1990) considers energy-efficiency choices in new office buildings in his typology of market failures and regulatory distortions. He identifies eight types of failures, some pertaining to the markets themselves (imperfect cornpetition, side effects, public goods, cash-flow constraints), some to government policy (regulatory distortions), and some to consumer behavior (information collection, economic non-rationality, risk aversion).

- Sutherland (1991) argues that the external costs of energy production and consumption and the lack of aggregate insurance against energy-related risk are the only factors standing in the way of optimal societal investment in efficiency. Other factors thought to comprise barriers are merely expressions of the illiquidity and risk associated with energy-efficiency investments and therefore entirely appropriate in a properly functioning market.

- Shankle and Eckert studied the energy-efficiency decision making of industrial firms in a 1992 report to the US Department of Energy. They found, "Although economic considerations are usually the key criteria used by industrial firms when making decisions on investments, noneconomic criteria also significantly effect investment decisions" (p. iii) ${ }^{7}$ They conclude that inter-project competition, risk perception, lack of information, shortage of low-cost projects, funding delays, and weak corporate and national commitment to conserving energy pose significant barriers to conservation investment.

- Howarth and Andersson (1992) show how the structural characteristics of markets for energyusing equipment may impede the adoption of cost-effective energy-efficient technologies even when markets are competitive and all market participants are rational. Consumer perceptions and anomalies in the transmission of information between producers and consumers have an important impact on the market potential of energy-efficient technologies.

- Lovins (1992) documents a market rife with inefficiency and "perverse" incentives. These inefficiencies are driven mainly by the difficulty of creating optimized, custom-built buildings systems in the face of persistent institutional failures. One important failure is the prevailing fee structures of building design engineers, which are explicitly or implicitly based on a percentage of the capital cost of the project. These fee structures are pernicious because good design for HVAC systems will allow substantial reductions in capital costs and operating costs. Such design requires additional expenditures beyond the typical "rule-of-thumb" equipment sizing that most engineers do, which results in a net penalty for designers of efficient systems. Lovins also discusses a variety of other institutional failings, including nonexistent or faulty operation, monitoring, post-occupancy evaluation, maintenance, and building commissioning.

- A 1994 analysis of the literature by Golove (Golove, 1994) led him to conclude the preponderance of both market failures and barriers tend to generate a systematic underinvestment in energy efficiency. Golove's market failures include negative environmental and

\footnotetext{
${ }^{7}$ Non-economic criteria include plant requirements, effects on product quality, technology availability, legal and regulatory issues, training requirements, personal preferences, plant performance, public image, and aesthetics.
} 
national security externalities, and utility mis-pricing by average rather than marginal production costs. Barriers considered include lack of consumer awareness, mis-placed incentives, liquidity constraints, and inseparability of features (called "gold plating" in other literature).

- Koomey and Sanstad (1994) take a close look at four specific markets for energy-efficient products and conclude that market failures such as information problems, decision-making problems, capital market imperfections, search costs or other imperfections must be inhibiting the adoption of more efficient technologies.

- Jaffe and Stavins (1994) attempt to disentangle arguments about the existence of the efficiency gap by identifying five separate and distinct notions of optimality and distinguishing between market failures and non-market failures.

- Koomey, Sanstad, and Shown (1995) examine the market for magnetic fluorescent ballasts and conclude that the workings of this market provide strong evidence for the existence of economic inefficiency in this markets for a particular energy-efficient technology.

- Golove and Eto (1996) provide a valuable service by summarizing the debate over the existence of the efficiency gap and considering its implications for public policies to promote energy efficiency. They first explain seven market barriers, ${ }^{8}$ then show how many of them may be understood as examples of market failures such as externalities, imperfect competition, public goods, and imperfect information. Next they discuss how transaction cost theory might enhance understanding of information-related market failures in particular and as a framework for assessing energy-efficiency policies.

\section{Neoinstitutional Economics}

- DeCanio (1993) provides several possible reasons for corporate practices such as high hurdle rates that preclude efficient levels of investment in energy efficiency. All of them address the way people in organizations process and act upon information, including bounded rationality, principle-agent problems, moral hazard, and statistical or selection bias in estimating investment returns. DeCanio argues such non-market barriers cannot be surmounted with traditional regulatory approaches because they are an outgrowth of ". . . internal informational and incentive factors that have little to do with the neoclassical optimization paradigm" (p. 912).

- Hassett and Metcalf (1993) argue that uncertainty, heterogeneity of consumers, and option value provided by waiting to invest in energy-efficiency improvements can account for discount rates about four times higher than the standard rate. They therefore conclude, "...the apparently high discount rates attributed to investors making energy conservation investments are not irrational or the result of some market failure" (p. 710). Howarth and Sanstad (1995, below) refute this argument.

- DeCanio (1994) analyzed survey results and conducted in-depth interviews with participants in the EPA's Green Lights program to explore the apparent failure by firms to maximize shareholder wealth by under-investment in energy efficiency. He found that:

...the picture that emerged was a consistent one of barriers to profitable investment arising as unintended or unavoidable consequences of other strategies adopted by the firms - to decentralize decision-making, exercise control over operations, or routinize the evaluation of small projects. (p. 113)

- Sanstad and Howarth (1994) relax neoclassical assumptions about the information gathering and optimization abilities of individuals and firms to "...suggest that many of the 'market

\footnotetext{
8 Misplaced incentives, lack of access to financing, flaws in market structure, mis-pricing imposed by regulation, decisions influenced by custom, lack of or mis-information, and "gold plating"
} 
barriers' to energy efficiency discussed in the literature may be understood as market failures properly construed" (p. 817). They suggest information economics bridges the gap between engineering and neoclassical economics approaches to energy policy by recognizing that "normal" markets are not necessarily efficient.

- Howarth and Sanstad (1995) provides both a summary and response to many approaches to explaining the "efficiency gap", particularly Sutherland (1991) and Hassett and Metcalf (1993). They argue that high discount rates in energy-related decisions cannot be fully explained by hidden costs, consumer heterogeneity, or perceived risk. Neither can they be attributed to uncertainty and the irreversibility of efficiency investments. Rather, new research on the problems of market failures related to transaction costs, asymmetric information and bounded rationality in business organizations reveals, "...firms are more complicated and perhaps less efficient than simple profit-maximization models suggest, even when managers and employees are perfectly rational" (p. 107).

- Sanstad, Blumstein, and Stoft (1995) use Hassett and Metcalf's (1993) own model and data to demonstrate:

...even taking uncertainty and irreversibility in to account in the manner they [Hassett and Metcalf] propose, consumers must still be applying anomalously high rates of time discounting to yield implicit discount rates in the range reported in the literature. (p. 739)

\section{Transaction Costs}

- Hein and Blok (1994) conducted a survey of twelve energy coordinators in industry to obtain an estimate of the magnitude of transactions costs of energy conservation measures. Transaction costs estimated included collecting information, decision-making, implementation, and monitoring. These costs were found to be quite small (between one and six percent) for retrofit installation of energy-efficient technologies of total project costs. "Hence," they conclude, "transaction cost may only partly explain why large firms do not apply the full potential of energy-efficiency improvement".

- Johnson and Bowie view energy efficiency as a coordination problem in their 1994 paper. In this context transactions become a matter of cooperation between buyers and sellers, commitment among buyers, and competition among sellers. Their exploration comes to the following conclusion:

Factors that are neglected or ignored in the neoclassical model take on crucial significance with respect to bringing the transactions of new energy-efficient products to fruition, such as the specification of contractual alternatives, the process of negotiating changes, measurement of technical specifications, and the monitoring and enforcement of contractual obligations. (p. 12)

- Also see Golove and Eto (1996) above.

\section{Organizational Approaches}

- A study for the Alliance to Save Energy conducted by Ross (1986) collected data about capital budgeting practices from fifteen large industrial firms. He argues the structure of the budget process itself causes under-investment in energy conservation projects. In firms where capital is rationed so energy efficiency-improving projects must compete against each other rather than a profitability standard, smaller projects face such high hurdle rates $(25-60 \%)$ that significant opportunities for profits are forgone. Ross also found while project proposers often perform 
discounted cash flow evaluations, decision-makers most often use simple figures such as payback period to compare projects to each other - again foregoing profitable opportunities.

- Cebon (1992) used comparative case data from two universities to develop an organizational model of energy conservation decision-making. This model emphasizes power and incentive distribution and information acquisition and analysis. He finds the structure of an organization largely prescribes the capacity of its energy managers to acquire and analyze the information they need to make sound investment decisions. More important, organizational structure constrains the power of energy managers to implement their decisions for the benefit of the institution as a whole.

- DeCanio and Watkins (1995) examined whether firms' characteristics influence their decision to invest in lighting retrofits by using information from Environmental Protection Agency and Securities and Exchange Commission databases. They found, contrary to the predictions of economic theory, the characteristics of a firm (such as size, earnings per share, industrial sector) influence its probability of joining the Green Lights program. DeCanio (1995) states even more strongly, ". . . organizational and institutional factors appear to be at least as important as economic ones in explaining the performance of the lighting upgrade investments" (p. 15) and "the data reinforce the view that there is a large potential for profitable energy-saving investments that is not being realized because of impediments that are internal to private and public-sector organizations" (p. 22).

\section{Behavioral Approaches}

- Komor and Katzev (1988) used personal interviews to explore behavioral issues influencing energy use in small commercial buildings. They found in these cases that poor information, perceived lack of control over energy costs, belief that energy conservation means reduced comfort, diffusion of responsibility, and the magnitude of energy costs compared to total sales were significant barriers to efficiency investment.

- Goitein (1989) conducted a survey of participants in a commercial energy audit program. They found the garbage can model of organizational decision-making a helpful way of explaining which businesses chose to participate in the audit and why "energy champions" and having many projects available for consideration are vital to implementing audit recommendations. 


\section{APPENDIX REFERENCES}

Cebon, Peter B. "“Twixt Cup and Lip: Organizational Behavior, Technical Prediction and Conservation Practice”. Energy Policy.. September, 1992. pp. 802-814.

Coase, Ronald H. “The Nature of the Firm". Economica. Vol. 4. 1937. pp. 386-405.

Cyert, Robert and March, John. A Behavioral Theory of the Firm.. 1963. Prentice Hall. Englewood.

DeCanio, Stephen. "Agency and Control Problems in US Corporations: The Case of Energyefficient Investment Projects". Journal of the Economics of Business. Vol. 1, No. 1. 1994. pp. 105123.

DeCanio, Stephen J. "Barriers within Firms to Energy-Efficient Investments". Energy Policy. September, 1993. pp. 906-914.

DeCanio, Stephen J. and Watkins, William E. "Investment in Energy Efficiency: Do the Characteristics of Firms Matter?". October, 1995. Department of Economics, University of California at Santa Barbara.

DeCanio, Stephen J. "The Energy Paradox: Bureaucratic and Organizational Barriers to Profitable Energy-Saving Investments”. August, 1995. Department of Economics, University of California at Santa Barbara.

Eggertsson, Thrainn. Economic Behavior and Institutions. 1990. Cambridge University Press.

Goitein, Bernard. "Organizational Decision-Making and Energy Conservation Investments". Evaluation and Program Planning. Vol. 12. 1989. pp. 143-151.

Golove, William H. "Are Investments in Energy Efficiency Over or Under?: An Analysis of the Literature". ACEEE 1994 Summer Study on Energy Efficiency in Buildings.. Vol. 1. 1994. American Council for an Energy-Efficient Economy. pp. 37-43.

Golove, William H. and Eto, Joseph H. "Market Barriers to Energy Efficiency: A Critical Reappraisal of the Rationale for Public Policies to Promote Energy Efficiency". March, 1996. Energy and Environment Division, Lawrence Berkeley National Laboratory.

Hassett, Kevin A. and Metcalf, Gilbert E. "Energy Conservation Investment: Do Consumers Discount the Future Correctly?'. Energy Policy.. June, 1993. pp. 710-716.

Hein, Lars G. Blok, Kornelis. "Transaction Costs of Energy Efficiency Improvement". Proceedings 1994.. European Council for an Energy Efficient Economy.

Howarth, Richard B. and Sanstad, Alan H. "Discount Rates and Energy Efficiency". Contemporary Economic Policy. Vol. 13. July, 1995. pp. 101-109.

Howarth, Richard B. and Andersson, Bo. "Market Barriers to Energy Efficiency". Revised July, 1992. Energy and Environment Division, Lawrence Berkeley National Laboratory.

Jaffe, Adam B. and Stavins, Robert N. "The Energy Efficiency Gap: What Does It Mean?". Energy Policy. Vol. 22, No. 10. 1994. pp.804-810. 
Johnson, Francis X. and Bowie, Randall. "Transaction Costs, Energy Efficiency and Institutional Design". IAEE 17th Annual International Energy Conference Proceedings.. Vol. 3. 1994. pp. 113. Stavenger, Norway.

Komor, Paul S. and Katzev, Richard. "Behavioral Determinants of Energy Use in Small Commercial Buildings: Implications for Energy Efficiency". Energy Systems and Policy. Vol. 12. pp. 233-242.

Koomey, John G., Sanstad, Alan H.and Shown, Leslie J. "Magnetic Fluorescent Ballasts: Market Data, Market Imperfections, and Policy Success". December, 1995. Energy and Environment Division, Lawrence Berkeley National Laboratory.

Koomey, Jonathan G. Energy Efficiency Choices in New Office Buildings: An Investigation of Market Failures and Corrective Policies. PhD dissertation. 1990. University of California at Berkeley.

Koomey, Jonathan G. and Sanstad, Alan H. "Technical Evidence for Assessing the Performance of Markets Affecting Energy Efficiency”. Energy Policy. Vol. 22, No. 10. 1994.

Lovins, Amory B. 1992. Energy-Efficient Buildings: Institutional Barriers and Opportunities. ESource. Strategic Issues Paper. December.

March, James and Olsen, Johan. Ambiguity and Choice in Organizations.. 1976. Universitetsforlaget. Bergen, Norway.

March, James G. and Olsen, Johan P. "Garbage Can Models of Decision Making in Organizations". Ambiguity and Command: Organizational Perspectives on Military Decision Making. 1986. Pitman Publishing, Inc. pp. 11-35. Marshfield, MA.

Milgrom, Paul and Roberts, John. "Bargaining and Influence Costs and the Organization of Economic Activity". Working paper. February 27, 1987. University of California, Berkeley, Economics Department.

Milgrom, Paul and Roberts, John. Economics, Organization, and Management . 1992, Prentice Hall. Englewood Cliffs.

Pruitt, Stephen W. and Gitman, Lawrence J. "Capital Budgeting Forecast Biases: Evidence from the Fortune 500". Financial Management. Spring, 1987. pp. 46-51.

Ross, Marc. "Capital Budgeting Practices of Twelve Large Manufacturers". Financial Management. Winter, 1986. pp. 15-22.

Sanstad, Alan H., Blumstein, Carl, and Stoft, Steven. "How High Are Option Values in EnergyEfficiency Investments?". Energy Policy. Vol. 23, No. 9. 1995. pp. 739-743.

Sanstad, Alan H. and Howarth, Richard B. “'Normal' Markets, Market Imperfections, and Energy Efficiency”. Energy Policy. Vol. 22, No. 10. 1994. pp. 811-818.

Shankle, D.L. and Eckert, R.L. "Industrial Energy Efficiency Decision Making". September, 1992. Pacific Northwest Laboratory.

Statman, Meir and Tyebjee, Tyzoon. "Optimistic Capital Budgeting Forecasts: An Experiment". Financial Management. Autumn, 1985. pp. 27-33. 
Sutherland, Ronald J. "Market Barriers to Energy-Efficiency Investments". The Energy Journal. Vol. 12, Number 3. 1991. pp. 15-34.

Velthuijsen, Jan Willem. "Determinants of Investment in Energy Conservation". PhD dissertation. 1995. University of Amsterdam.

Williamson, Oliver. "Operationalizing the New Institutional Economics: The Transaction Cost Imperative". Business and Public Policy Working Paper. 1989. University of California, Berkeley Business School. 